\title{
The fasting metabolism of adult wether sheep
}

\author{
BY K. L. BLAX'TER \\ Hannah Dairy Research Institute, Kirkhill, Ayr \\ (Received 6 March I962-Revised I3 Fune 1962)
}

The heat produced when an animal is fasted in an environment which is neither too hot nor too cold to cause increases in metabolism is a measure of the energy needed to maintain that animal. When man is the subject, muscular repose can invariably be assured and the measurement of heat production is termed the basal metabolism. Most animals do not co-operate in the way that man does and their heat production during fasting thus includes some heat incidental to normal body movement. The measurement is, therefore, best termed the fasting metabolism.

Many thousands of determinations of the basal metabolism of man have been made and have recently been reviewed in detail by Quenouille, Boyne, Fisher \& Leitch (195I). No studies on any similar scale have been made of the fasting metabolism of sheep, though notable investigations have been made by Ritzman \& Benedict (1930, I93 I), Lines \& Pierce (193I) and Marston (1948). In addition, Brody (1945) has made a number of determinations of heat production in sheep at various times after food. During the past 7 years, the fasting metabolism of adult wether sheep has been determined in this laboratory on many occasions during the course of other experiments and this paper is concerned with analysis of the results.

\section{EXPERIMENTAL}

Animals. The sheep used were all castrated males. The breeds were Scottish Blackface, Cheviot and Down crosses. Before experiments began the sheep were trained to become accustomed to the apparatus. Graham (I958) showed that, when untrained sheep were fasted, heat production was $20 \%$ higher than it was in the same individuals 3 weeks later after they had been accustomed to confinement.

Method of determination of fasting metabolism. A standard method was used. The sheep was given a ration of hay or dried grass, calculated to be sufficient to prevent its losing or gaining weight, for at least 7 days before the determination of fasting heat production began. This procedure was adopted because Marston (I948) showed that the level of feeding of sheep before a fast had a marked effect on the length of time it took to reach a minimal metabolism. The sheep was given its last meal at 5 p.m. and metabolism determinations were commenced at 9 a.m. the following morning and were continued until 9 a.m. 4 days later. The total length of fast was thus $\mathrm{I} I 2 \mathrm{~h}$. All sheep had access to unlimited water though they consumed little. On each of the 4 days of the experiment, oxygen consumption, carbon dioxide production, methane production and excretion of nitrogen in the urine were measured. The sheep was 
weighed at the beginning of the Ist day ( $16 \mathrm{~h}$ after food), the beginning of the $3^{\text {rd day }}$ ( $64 \mathrm{~h}$ after food) and at the end of the 4 th day ( $112 \mathrm{~h}$ after food). For convenience the four consecutive $24 \mathrm{~h}$ periods are referred to as days of fast, although the ist day refers to measurements commencing $\mathrm{I} 6 \mathrm{~h}$ after food.

The fasting metabolism of the sheep was taken to be the mean heat production on the $3^{\text {rd }}$ and $4^{\text {th }}$ days of fast (64-II $\mathrm{h}$ after food) and the reference body-weight the mean weight during the same period. The results of twenty-three experiments of this type are reported in detail and the results of a further fifty-five experiments have been considered. The results apply to thirty-four individual sheep. Many of these observations were made incidentally to other experiments, and some of the determinations have been included in the following papers: Blaxter \& Graham (1955, 1956), Blaxter, Graham \& Wainman (1956), Armstrong \& Blaxter (1957b), Armstrong (1960), Blaxter \& Wainman (1961), Graham (1958).

Longer fasts. During experiments in which volatile fatty acids or glucose were given by infusion into the rumen or the abomasum of cannulated sheep, the sheep subsisted for longer periods without solid food. These periods were of II or 12 days' duration. In these experiments infusions were begun at the I I 2 th $h$ and terminated 4 days later $(208$ th $\mathrm{h}$ ). The sheep was then given no food or potentially metabolizable material for the subsequent 3 or 4 days, that is until a maximum of $304 \mathrm{~h}$ after the last meal of solid food. The results of seventeen such experiments are discussed here; most of them have been published (Armstrong \& Blaxter, 1957 $a$; Armstrong, Blaxter \& Graham, 1957, 1961).

Environmental conditions. In early experiments environmental temperatures in the respiration apparatus were kept at $19-22^{\circ}$. In one or two experiments with sheep with short fleeces, it was clear that this environmental temperature was too low, for the sheep were observed to shiver. These experiments were abandoned. After completion of studies on the effect of environment on the metabolism of the sheep and the definition of the insulating value of fleece (Graham, Wainman, Blaxter \& Armstrong, 1959; Blaxter et al., 1959), the environmental temperature in the respiration chamber was adjusted in each experiment so that it was well above the estimated critical temperature of the sheep. With some newly shorn sheep with short fleeces, this condition necessitated operation of the chambers at $30^{\circ}$. With sheep with more than $5 \mathrm{~cm}$ of fleece, a temperature of $22^{\circ}$ was adequate.

Procedure at the end of fasts. Though not relevant to the results given in this paper, the methods adopted to ensure recovery of the sheep from fasts are presented because they proved important in ensuring the well-being of the sheep stock. After short fasts of 4 days, the sheep were given an inoculum of rumen fluid by mouth and offered dried grass in small amounts (200-400 g/day) for a period of 4 days, when appetite was usually restored. With longer fasts, all of which were made with cannulated sheep, the sheep were first provided with a readily available source of energy, either by giving them cow's milk directly into the rumen or glucose into the abomasum. Very small amounts of dried grass (100-200 g) were then offered and inocula of rumen fluid were given. The sheep were kept warm and usually they regained appetite and rumen function within 6 days of the termination of the fast. 
Calorimetric technique. The respiration chambers used to determine heat production were initially those of Blaxter, Graham \& Rook (r954) and later the improved chambers of Wainman \& Blaxter (1958).

Analytical methods. In urine, $\mathrm{N}$ was determined by Kjeldahl's method and heat of combustion by bomb calorimetry.

\section{RESULTS}

Heat production during short fasts. The criteria usually adopted as showing that a ruminant is in the true fasting state, that is when heat production no longer reflects the continuing metabolism of food, are, first, the disappearance of methane production and, secondly, a fall of the respiratory quotient to values which show that no food carbohydrate is being oxidized. The results of twenty-three experiments in which nine sheep were fasted for the standard period of 4 days are shown in Table $\mathrm{r}$. These determinations were made during 1959-60. At the levels of feeding used before fasting began, methane production was $20-351$./day and the respiratory quotient close to $1 \cdot 0$. The results in Table I show that methane production fell markedly during the fasts, but that methane was still being produced at a rate of $1 \cdot 61 . / 24 \mathrm{~h}$ on the $4^{\text {th }}$ day of fast, which shows that fermentation of food continued for 4 days. The fall in methane production from the $3^{\text {rd }}$ to the $4^{\text {th }}$ day was significant $(P<0.01)$. Analysis of variance also showed that some animals produced significantly more methane than others.

The respiratory quotients in Table $\mathrm{I}$ are the ratios of volume of $\mathrm{CO}_{2}$ produced to volume of $\mathrm{O}_{2}$ consumed, and have not been corrected for urinary losses of $\mathrm{N}$. Though

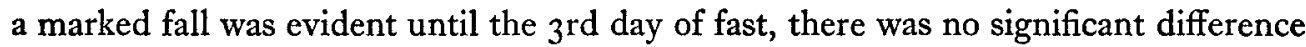
between the respiratory quotients determined on the $3^{\text {rd }}$ and on the $4^{\text {th }}$ day. The mean value of 0.73 for an uncorrected respiratory quotient is intermediate between a value of $0.7 \mathrm{I}$ for that of body fat and of $0.8 \mathrm{I}$ for body protein (Lusk, 1931), and shows that about $20 \%$ of the heat produced was derived from protein. This percentage agrees with the estimates made from the $\mathrm{N}$ metabolism of the sheep (see p. 623). These results show that little, if any, carbohydrate was being oxidized on the $3^{\text {rd day and that }}$ a true fasting metabolism had been attained.

The heat production of all sheep was lower on the $4^{\text {th }}$ day than on the $3^{\text {rd }}$ day, the mean fall being $3.7 \%$. This fall was highly significant statistically. The sheep were weighed at the beginning of the 3 rd and end of the $4^{\text {th }}$ day. The mean daily fall in body-weight of the sheep was $I \cdot 3 \%$. Heat production thus fell at a higher rate during fasting than did body-weight.

Heat production during fasts longer than 4 days. The results of seventeen experiments in which sheep with cannulated rumens were initially fasted for 4 days, infused with steam volatile fatty acids, singly or in mixtures for 4 days and subsequently fasted again, are given in Table 2. In none of these experiments was the energy given as volatile fatty acids sufficient to cause energy retention to become positive, and in most instances the increase in energy retention above the base-line of fasting energy retention when supplements were given was less than a third of the fasting energy loss. The sheep continued to produce small amounts of methane on the I I th day of fast, though on some occasions the amount found was so small that it was of the same order as 


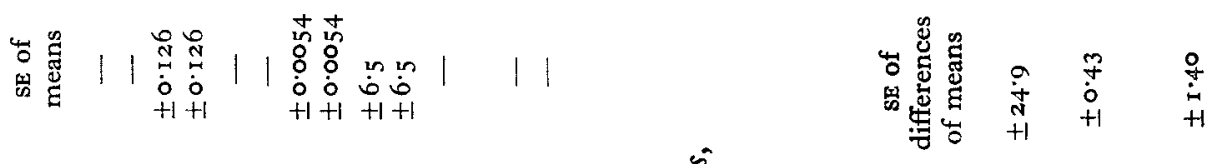

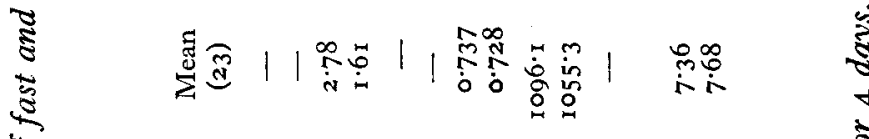

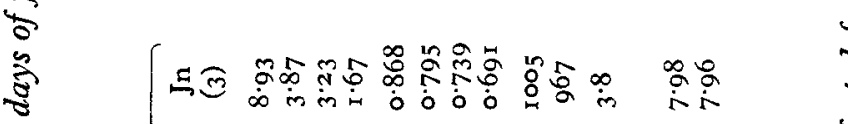

हैं

弯

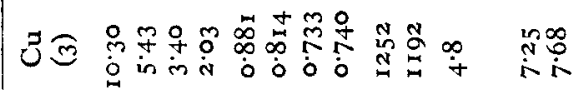

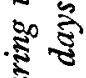

胥

D匀

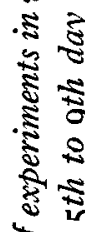

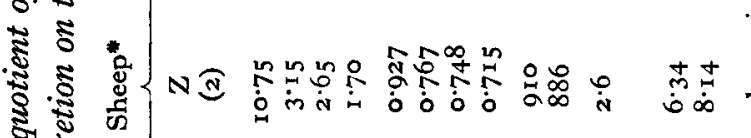

ते है

z

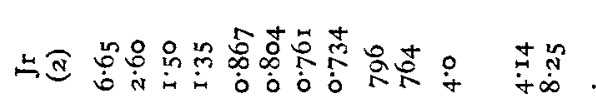

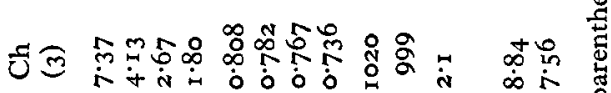

. ल क

i.

昰

ङँ

๓

고ำ

곤

莡

क.

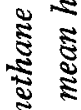

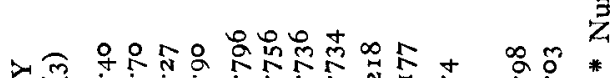

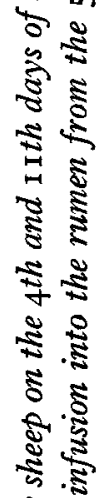

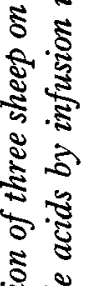

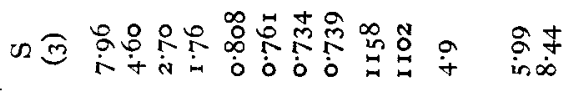

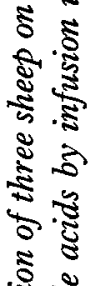

ज्ञ

కั้

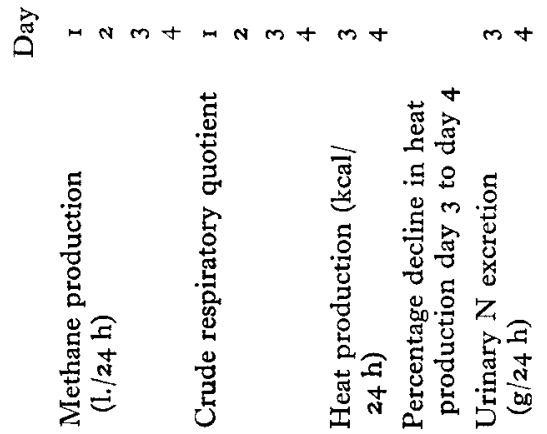

2 으

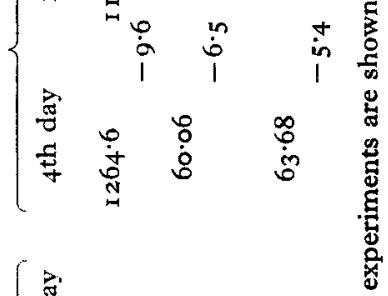

*

竎 $\frac{2}{2}$

ह

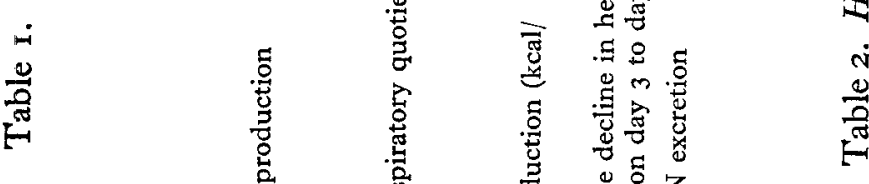

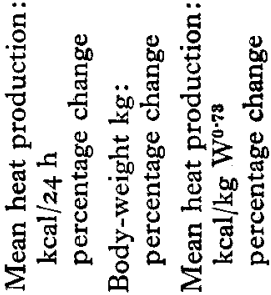


the error associated with its determination (about $\pm 0 \cdot 21 . / 24 \mathrm{~h}$ ). Heat production on the I Ith day of fast was $10 \%$ lower than on the $4^{\text {th }}$ day of fast. In the interim, body-weight had fallen by $7 \%$. Expressed per unit weight, heat production had thus fallen from 20.8 to $20.2 \mathrm{kcal} / \mathrm{kg} 24 \mathrm{~h}$ or by $2.7 \%$, and expressed per $\mathrm{kg}$ metabolic body size (body-weight raised to the power 0.73 (Brody, 1945)), heat production had fallen from 63.5 to $6 \mathrm{r} \cdot \mathrm{I} \mathrm{kcal} / \mathrm{kg} \mathrm{W0.73} 24 \mathrm{~h}$, or by $3.9 \%$.

These results and those for the shorter fasts suggest that after the 64th $\mathrm{h}$ after food, the heat production of the fasting sheep falls continuously and that body-weight falls at a slightly slower rate. Lusk (193I) has summarized experiments in which man has been fasted for long periods. These show that the absolute heat production of man, his heat production per unit weight and his heat production per $\mathrm{m}^{2}$ body surface, all decline continuously during fasting. Similar declines in heat production during long fasts have been noted with suckling calves (Blaxter, 1950).

Constancy of the fasting metabolism of individual sheep. A variation in heat production from sheep to sheep is evident from Table $I$ and analysis of variance of those results showed the differences between the metabolism of individuals to be statistically significant. The standard deviation of an individual experiment computed from the within-sheep term of the analysis of variance was $\pm 43 \mathrm{kcal} / 24 \mathrm{~h}$. Table 3 gives the results of five fasting measurements made with each of two sheep, $\mathrm{Y}$ and $\mathrm{Z}$, extending

\section{Table 3. Heat production of sheep $Z$ and sheep $Y$ (born in 1955) determined on} the $3^{\text {rd }}$ and 4 th days of fast on different occasions

\begin{tabular}{|c|c|c|c|c|c|c|c|c|}
\hline \multirow[b]{3}{*}{ Date of experiment } & \multirow{2}{*}{\multicolumn{2}{|c|}{$\begin{array}{l}\text { Weight of sheep } \\
\text { with fleece } \\
(\mathrm{kg})\end{array}$}} & \multicolumn{6}{|c|}{ Heat production } \\
\hline & & & \multicolumn{2}{|c|}{$\mathrm{kcal} / 24 \mathrm{~h}$} & \multicolumn{2}{|c|}{$\mathrm{kcal} / \mathrm{kg} 24 \mathrm{~h}$} & \multicolumn{2}{|c|}{$\begin{array}{l}\mathrm{kcal} / \mathrm{kg} \mathrm{W} \mathrm{W}^{0.73} \\
24 \mathrm{~h}\end{array}$} \\
\hline & $\begin{array}{c}\text { Sheep } \\
\text { Z }\end{array}$ & $\begin{array}{c}\text { Sheep } \\
\text { Y }\end{array}$ & $\begin{array}{c}\text { Sheep } \\
Z\end{array}$ & $\begin{array}{l}\text { Sheep } \\
\text { Y }\end{array}$ & $\begin{array}{c}\text { Sheep } \\
Z\end{array}$ & $\begin{array}{l}\text { Sheep } \\
\mathrm{Y}\end{array}$ & $\begin{array}{c}\text { Sheep } \\
\text { Z }\end{array}$ & $\begin{array}{c}\text { Sheep } \\
\text { Y }\end{array}$ \\
\hline $\begin{array}{l}\text { September } 1959 \\
\text { March I } 960 \\
\text { July 1960 } \\
\text { March-April 1961 } \\
\text { January } 1962\end{array}$ & $\begin{array}{l}53 \cdot 4 \\
57 \cdot 1 \\
61 \cdot 4 \\
60 \cdot 4 \\
64 \cdot 8\end{array}$ & $\begin{array}{l}6 x \cdot 5 \\
66 \cdot 1 \\
63 \cdot 7 \\
67 \cdot 3 \\
66 \cdot 5\end{array}$ & $\begin{array}{r}878 \\
918 \\
\text { IO24 } \\
989 \\
957\end{array}$ & $\begin{array}{l}1163 \\
1252 \\
1220 \\
1248 \\
1159\end{array}$ & $\begin{array}{l}16 \cdot 4 \\
16 \cdot 1 \\
16 \cdot 7 \\
16 \cdot 4 \\
14 \cdot 8\end{array}$ & $\begin{array}{l}18 \cdot 9 \\
18 \cdot 9 \\
19 \cdot 2 \\
18 \cdot 5 \\
17 \cdot 4\end{array}$ & $\begin{array}{l}47 \cdot 4 \\
47 \cdot 2 \\
50 \cdot 4 \\
49 \cdot 5 \\
45 \cdot 4\end{array}$ & $\begin{array}{l}56 \cdot 1 \\
58 \cdot 1 \\
57 \cdot 8 \\
57 \cdot 8 \\
54 \cdot 2\end{array}$ \\
\hline $\begin{array}{l}\text { Mean } \\
\text { Standard deviation } \\
\text { Coefficient of variation }(\%)\end{array}$ & $-\ldots$ & - & $\begin{array}{r}953 \\
57 \cdot 5 \\
6 \cdot 0\end{array}$ & $\begin{array}{r}1208 \\
45^{\circ} \circ \\
3 \cdot 7\end{array}$ & $\begin{array}{l}16 \cdot 1 \\
0 \cdot 74 \\
4 \cdot 6\end{array}$ & $\begin{array}{l}18.6 \\
0.71 \\
3.8\end{array}$ & $\begin{array}{l}48 \cdot 0 \\
I \cdot 98 \\
4 \cdot I\end{array}$ & $\begin{array}{l}56 \cdot 8 \\
1 \cdot 65 \\
2 \cdot 9\end{array}$ \\
\hline
\end{tabular}

W, body-weight. Sheep Z, Scottish Blackface; sheep Y, Suffolk cross.

the curtailed results for these two animals given in Table I. These sheep were two which had been noted in 1959 as having a high and a very low heat production when it was expressed on the basis of weight raised to the power 0.73 . Sheep $Y$ was a Suffolk cross and sheep $Z$ a pure-bred Scottish Blackface. Both were about the same age and had been treated similarly since 1956 when they were bought, except that sheep $\mathrm{Z}$ had been used as an experimental animal during $195^{6}$ and 1957 whereas sheep Y had not.

The results in Table 3 show that differences in the fasting heat production of these 
two sheep persisted over a period of 2 years. The standard deviation of the measured heat production was $\pm 5^{8} \mathrm{kcal} / 24 \mathrm{~h}$ with one sheep and \pm 45 with the other, in good agreement with the estimates of variation obtained in the analysis of the results given in Table $\mathrm{x}$. Variation was slightly less when account was taken of differences in the size of the sheep, either by expressing heat production per $\mathrm{kg}$ body-weight or per $\mathrm{kg}$ body-weight raised to the power 0.73 (metabolic body size). The difference in the heat production of these individuals was considerable. Sheep Y produced $18 \%$ more heat per $\mathrm{kg}$ metabolic size and $\mathrm{I} 2 \%$ more heat per $\mathrm{kg}$ body-weight than did sheep $\mathrm{Z}$.

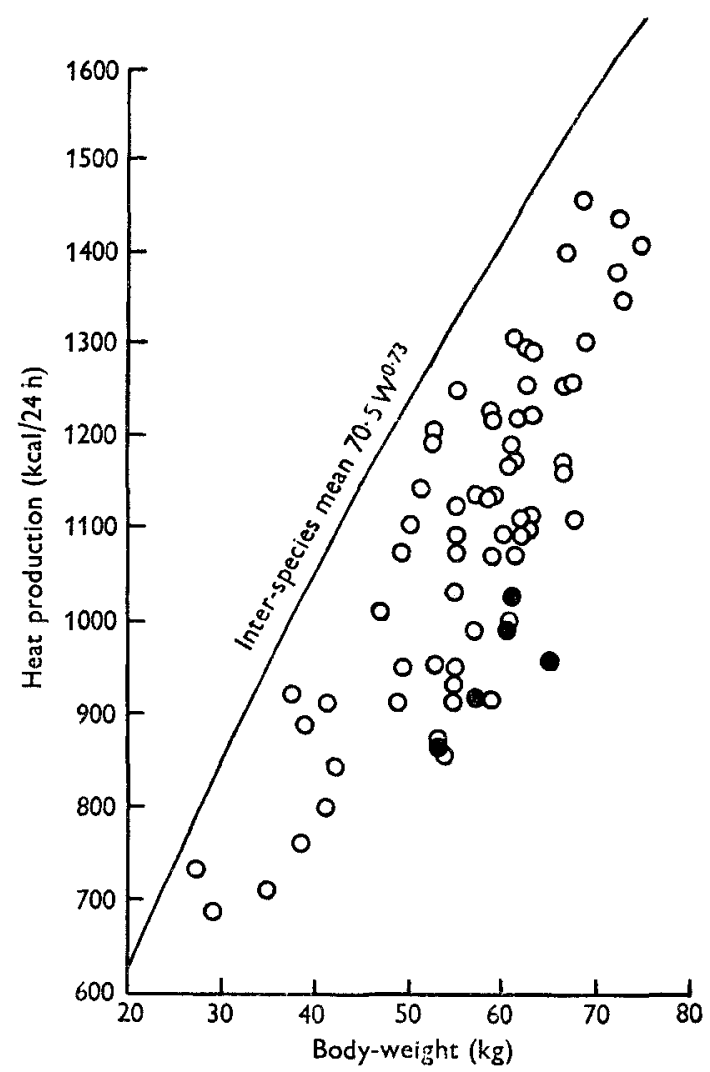

Fig. $x$. Heat production of sheep over 2 years of age in relation to their weight. $\bullet$, Results for sheep $Z$ as given in Table 3 . The line is that which relates fasting metabolism to weight in adults of different species calculated according to Brody's (1945) formula: heat production $(\mathrm{kcal} / 24 \mathrm{~h})=70.5$ body-weight $(\mathrm{kg})^{0.73}$.

Effect of weight of sheep. Kleiber (1932) and Brody \& Proctor (1932) investigated the relationship between body-weight and fasting heat production in mature animals of different species and found that metabolism increased with increasing weight in proportion to a power of the weight of about $0 \cdot 7$. A conference on energy metabolism sponsored by the (USA) National Research Council (I935) concluded and advised that the unit of reference for fasting metabolism should be body-weight raised to the power $0 \cdot 73$. This advice has been followed in this laboratory. 
The fasting weight of our sheep has ranged from $27 \mathrm{~kg}$ for a very small Cheviot to $72 \mathrm{~kg}$ for a very large Oxford Down cross; the majority of animals, however, have weighed between 50 and $60 \mathrm{~kg}$. The results of the twenty-three determinations shown in Table I together with forty-six additional determinations have been plotted in Fig. I. No determinations on sheep less than 2 years of age have been included in Fig. I and the total of sixty-nine determinations applies to thirty individuals, which can all be presumed to have been mature. In Fig. I, the results for sheep $Z$, the sheep known to have a very low metabolism for its size relative to that of other sheep, have been shown separately.

It will be noted that every one of the observations on sheep lies below the line which relates metabolism to body-weight in mature animals of different species, often called the 'mouse-elephant curve'. An increase in heat production with increasing weight of sheep is obvious and heat production in these sheep appears to be about $20 \%$ below that predicted from Brody's relationship.

No analysis of the results with sheep has been made to establish whether metabolism is proportional to body-weight raised to the power 0.73 . The variation in metabolism as between individuals and the limited range of body-weight clearly precludes achievement of any precision in such an estimate. The results in Fig. I indicate, however, that there is no reason to suppose that body-weight raised to the power 0.73 cannot be used as a convenient standard of reference for sheep of different weights.

Effect of age of sheep. Table 4 summarizes the results of determinations of the fasting metabolism of wether sheep.

Table 4. Mean heat production of wether sheep on the $3^{\text {rd }}$ and $4^{\text {th }}$ days of fast, classified according to age

\begin{tabular}{|c|c|c|c|}
\hline $\begin{array}{c}\text { Age group } \\
\text { (years) }\end{array}$ & $\begin{array}{l}\text { No. of } \\
\text { sheep* }\end{array}$ & $\begin{array}{c}\text { Fasting heat } \\
\text { production } \dagger \\
\left(\mathrm{kcal} / \mathrm{kg} \mathrm{W} W^{0.73} 24 \mathrm{~h}\right)\end{array}$ & $\begin{array}{l}\text { Standard deviation } \\
\text { (as percentage } \\
\text { of mean) }\end{array}$ \\
\hline$I-2$ & 9 & $63 \cdot x \pm 2 \cdot 0$ & \pm 9.5 \\
\hline $2-4$ & 20 & $5^{8 \cdot 5} \pm x \cdot 3$ & \pm 9.8 \\
\hline $4^{-6}$ & 26 & $55^{\circ} 4 \pm I \cdot I$ & \pm 9.9 \\
\hline Over 6 & 4 & $52.4 \pm 3.0$ & $\pm \pm 1 \cdot 4$ \\
\hline
\end{tabular}

W, body-weight.

* Refers to the number of individual animals in each age group, but the same individual sheep can and does appear in more than one age group.

+ Mean with its standard error, the between-sheep variance being determined separately for each age group.

A decline of the metabolism per unit body size of these sheep with advancing age is evident, heat production falling by about $20 \%$ over a 6 -year period. The standard deviations which include real variation between individuals as well as variation in the same individual on different occasions are about $\pm 10 \%$ of the mean in each age group. It has already been shown (see Table 2) that individuals of the same age and history can have widely different heat productions, and that the variation in the same individual from time to time is not large. Table 4 shows that the metabolism of the adult wether sheep tends to fall with age. Similar declines in basal metabolism of adult man occur after the age of 30 (Lusk, I93r). 
With several of the sheep with a cannulated rumen, metabolism has been determined over long intervals of time, and these sheep showed a decline in metabolism with age. Thus with sheep $\mathrm{S}$ fasting heat production determined at an age of 18 months was $69.2 \mathrm{kcal} / \mathrm{kg} \mathrm{W}{ }^{0.73}$, at 28 months $63.9 \mathrm{kcal} / \mathrm{kg} \mathrm{W} \mathrm{W}^{0.73}$ and at $7^{6}$ months $52.9 \mathrm{kcal} / \mathrm{kg}$ $\mathrm{W}^{0.73}$. With sheep T, metabolism was $65.3 \mathrm{kcal} / \mathrm{kg} \mathrm{W}^{0.73}$ at the age of 36 months and $5^{2} \cdot 6 \mathrm{kcal} / \mathrm{kg} \mathrm{W}^{0.73}$ at 7 I months. Over shorter periods of time in older sheep, declines in metabolism with age are not readily detected. It is difficult, for example, to conclude from Table 3 that the metabolism of sheep $\mathrm{Z}$ and sheep $\mathrm{Y}$ declined with age over the age span from $5^{2}$ to 79 months.

Effect of breed. The limited number of sheep of any one breed within a single age group, and the fact that the animals were drawn from many different sources and had had quite diverse experimental histories, make it undesirable to attempt to generalize from the results about breed differences in metabolism. Comparison is made more difficult because sheep of different breeds may be of different mean size. Inspection of the data within any one age group, however, showed no consistent differences in the fasting metabolism that could be referred to breed.

Energy losses in urine during fasting. The heat of combustion of the urine produced during fasting is considerably less than that of the urine produced when the animal is fed. Recent determinations of the heat of combustion of the urine voided by eighteen fasting sheep showed that a mean of $70.9 \mathrm{kcal}$ urinary energy were excreted daily on the $3^{\text {rd }}$ and 4 th days of starvation. When sheep are fed, losses of energy in urine are invariably greater than roo kcal and usually about $200 \mathrm{kcal} / 24 \mathrm{~h}$. The ratio, energy: $\mathrm{N}$ in the urine in these eighteen experiments was $9.0 \mathrm{kcal} / \mathrm{g} \mathrm{N}$, with a standard deviation of $\pm 1.9 \mathrm{kcal} / \mathrm{g} \mathrm{N}$. This ratio is very much lower than those observed during feeding $(20-35 \mathrm{kcal} / \mathrm{g} \mathrm{N})$, but higher than the ratio that would be expected if the sole nitrogenous excretory product was urea $(6 \mathrm{kcal} / \mathrm{g} \mathrm{N})$. When man is fasted, ratios of $9 \cdot 0-10 \cdot 0 \mathrm{kcal} / \mathrm{g} \mathrm{N}$ have also been recorded but in such subjects acetonuria occurs (Lusk, 1931). No acetonuria of similar magnitude occurs in sheep. The carbon-containing products that are responsible for the high ratio, energy: $\mathrm{N}$ in the urine of sheep fasted for 3-4 days have not been identified. Ratios determined in experiments lasting for II-I4 days, however, are lower than those determined on the $3^{\text {rd }}$ and $4^{\text {th }}$ day, which suggests that the latter reflect the continuing metabolism of food.

Protein and fat katabolism d.tring fasting. In Table $\mathrm{I}$ the amounts of $\mathrm{N}$ excreted in the urine of nine sheep on the $3^{\text {rd }}$ and 4 th days of fast are shown. Considerable variation was present from day to day. The variation is thought to be due largely to retention of urine in the bladder. Sheep reduce their water intake considerably during starvation and some drink none at all for 4 days. Urine volume is thus markedly reduced. If fasting sheep are given water by infusion into the rumen during a fast, when urine volume increases, variation in the amount of $\mathrm{N}$ excreted each day is considerably reduced. From the mean values in Table I for all twenty-three experiments, there is no reason to believe that urinary $\mathrm{N}$ excretion changes markedly from the $3^{\text {rd }}$ to the $4^{\text {th }}$ day.

The mean $\mathrm{N}$ excretion on the $3^{\text {rd }}$ and $4^{\text {th }}$ day can be used to measure the 
proportion of the total energy lost by the fasting sheep that it obtains from oxidation of body protein. The total energy lost during fasting is the sum of the heat lost and the heat of combustion of the urine excreted. 'The energy lost from the body by oxidation of protein is $35 \mathrm{kcal} / \mathrm{g}$ urine $\mathbf{N}$. This factor derives from analyses of the $\mathbf{N}$ and energy content of muscle (Franke \& Weniger, 1958).

Table 5. Loss of energy derived from protein, expressed as a percentage of total loss of energy from the body of sheep during the $3^{\text {rd }}$ and $4^{\text {th }}$ days of fust

\begin{tabular}{|c|c|c|}
\hline Sheep & $\begin{array}{c}\text { No. of } \\
\text { expcriments }\end{array}$ & $\begin{array}{l}\text { Loss of } \\
\text { protein energy }\end{array}$ \\
\hline s & 3 & 23.5 \\
\hline$Y$ & 3 & $21 \%$ \\
\hline B & 2 & 80.9 \\
\hline $\mathbf{J} \mathbf{r}$ & 2 & 26.6 \\
\hline$\angle$ & 2 & 26.4 \\
\hline Ch & 3 & 26.5 \\
\hline D) & 2 & $22 \cdot 6$ \\
\hline Cu & 3 & 21.4 \\
\hline Jn & 3 & $26 \cdot 2$ \\
\hline Mlean & 23 & $23.8 \pm 1.5 *$ \\
\hline
\end{tabular}

- Standird crror of mean.

'Table 5, which refers to the same nine shcep as 'Table 1 , summarizes such calculations. The results show that on an energy basis about $24 \%$ of the body tissue broken down in fasting consisted of protein. Conversely, $76 \%$ of the energy lost was derived from fat. When sheep are given maintenance rations and then small supplements of food, they retain energy, and the proportion of energy retained as protein is about 18-25\% (Blaxter \& Martin, 1962; Armstrong \& Blaxter, 1957 b). This suggests that the ratio, fat:protein in the body tissue broken down in fasting is much the same as in the new tissue laid down when small weight gains are made.

\section{DISCUSSION}

The results for short fasts and long fasts indicate that food continues to be fermented in the alimentary tract of the sheep for long periods. On the $4^{\text {th }}$ day of fast the amount of methane produced is about $5 \%$ of that produced before the fast, and the ratio, energy: $N$ in urine on the $4^{\text {th }}$ day of fast suggests that carbon-containing substances derived from food are being excreted at that time. The respiratory quotients deter-

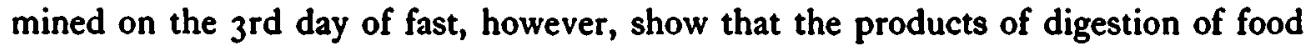
make no great contribution to the heat production of the animal, and the respiratory quotient does not fall significantly from the 3 rd to the $4^{\text {th }}$ day. Heat production on

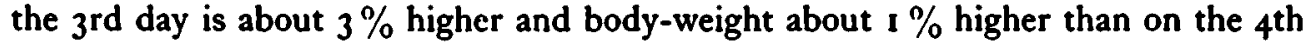
day. With continued fasting, heat production falls at a rate which is proportionatcly greater than the rate of fall in body-weight. The length of time which should be allowed after the fasting of a sheep begins before accepting a measurement of metabolism as indicative of a true fasting metabolism thus involves an element of choice. In this laboratory, measurements made between the 64th and 112 th $h$ of fast have been chosen as giving the best practical measure of minimal metabolism uncomplicated 
by the effects of continued fasting although they may include a very small amount of heat derived from the previous ration. The overestimation is thought to be less than $2 \%$ of the determined heat production.

The determinations of the fasting heat production of sheep by Ritzman \& Benedict (1930, 193 I) were made $24 \mathrm{~h}$ after food and have been termed 'standard metabolism' and those by Lines \& Pierce (193I) were made $48 \mathrm{~h}$ after food. In both series fasting metabolism is overestimated. The values obtained from the $64^{\text {th }}$ to the I I 2 th $\mathrm{h}$ of fast in our laboratory are $65 \%$ of those determined at the 24 th $\mathrm{h}$ and $88 \%$ of those determined at the 48 th $\mathrm{h}$ of fast. The determinations made by Marston (1948), however, are comparable to ours because care was taken to ensure low respiratory quotients by long fasts. Table 6 summarizes estimates of the fasting metabolism of sheep made in different laboratories. The results obtained by Benedict \& Ritzman have been corrected by multiplying them by 0.65 and those of Lines \& Pierce by multiplying them by $0 \cdot 88$. Marston's results like ours were expressed as $\mathrm{kcal} / \mathrm{kg}$ $\mathrm{W}^{0.73}$ and Brody's (1945) were estimated from the equation which he used to summarize his observations.

\section{Table 6. Estimates of the heat production of mature fasting sheep weighing $50 \mathrm{~kg}$ and aged 3-4 years}

\begin{tabular}{|c|c|c|c|}
\hline Breed of sheep & $\begin{array}{l}\text { Estimated } \\
\text { fasting } \\
\text { metabolism } \\
\text { (kcal/day) }\end{array}$ & Country & Reference \\
\hline $\begin{array}{l}\text { Wethers of mixed breeding } \\
\text { Merino ewes* } \\
\text { Durham } \dagger \text { wethers and ewes } \\
\text { Ewes (Hampshire) } f \\
\text { Merino wethersई }\end{array}$ & $\begin{array}{r}1018 \\
1030 \\
1027 \\
1087 \\
988\end{array}$ & $\begin{array}{l}\text { Scotland } \\
\text { Australia } \\
\text { USA } \\
\text { USA } \\
\text { Australia }\end{array}$ & $\begin{array}{l}\text { This paper } \\
\text { Marston (1948) } \\
\text { Ritzman \& Benedict (1930, 193I) } \\
\text { Brody (r945) } \\
\text { Lines \& Pierce (193I) }\end{array}$ \\
\hline
\end{tabular}

Benedict (1938), comparing the determinations of the metabolism of sheep made by Ritzman $\&$ Benedict and by Lines \& Pierce, concluded that there was 'a distinct racial difference in that the Australian race is on the whole $13 \%$ lower than the Durham race'. This conclusion was probably made without a realization of the importance of length of fast on the metabolism of sheep. In Table 6 it is seen that the application of corrections to the original results of Ritzman \& Benedict and of Lines \& Pierce virtually removes any difference between them. Further, the determinations made by Marston (1948) with Merinos in Australia agree very well with our determinations made in Scotland with sheep of a variety of breeds and crosses. In view of the variation of metabolism from individual to individual and the lack of any systematic 
variation in our determinations that could be attributed to breed, it seems unlikely that any major differences exist in the fasting metabolism of different breeds.

There is no doubt that the fasting metabolism of the adult sheep is considerably below that predicted from interspecies generalizations, such as those made by Brody \& Proctor (1932) and by Kleiber (1932). The former predicts a metabolism of $70.5 \mathrm{kcal} /$ $\mathrm{kg} \mathrm{W}^{0.73} 24 \mathrm{~h}$ for adult sheep. The values in Table 4 show that for sheep aged $4-6$ years, metabolism is $55^{\circ} 4 \pm \mathrm{I} \cdot \mathrm{I} \mathrm{kcal} / \mathrm{kg} \mathrm{W} W^{0 \cdot 73} 24 \mathrm{~h}$, that is $20 \%$ lower.

Why sheep should have a low metabolism relative to that of other species is not known. A low fasting metabolism is not peculiar to ruminants for, as judged by unpublished studies in this laboratory and studies in America (Kleiber, Regan \& Mead, 1945; Ritzman \& Benedict, 1938; Forbes, Fries, Braman \& Kriss, 1926), cattle have a fasting metabolism which is, if anything, higher than the inter-species mean. Kleiber (1947) has pointed out the evolutionary significance of a metabolic rate approximately proportional to surface area. On this basis it could be argued that in the evolution of sheep, fleece development has had greater survival value than has the development of a high metabolism per unit surface. It is difficult to provide any acceptable proof of this conjecture.

\section{SUMMARY}

I. The results of ninety-five determinations of the fasting metabolism of thirtyseven wether sheep were analysed.

2. Methane production from the $64^{\text {th }}$ to II2th h of fast was about $5 \%$ of that noted before fasting and the ratio, energy : nitrogen in urine was $9 \cdot 0 \mathrm{kcal} / \mathrm{g} \mathrm{N}$, suggesting a small continuing metabolism of food. The respiratory quotient was stable at the 64 th h.

3. After the $64^{\text {th }} \mathrm{h}$ of fast, heat production declined at a faster rate than did bodyweight. All measurements were standardized to the 64 th -112 th h of fast.

4. Large differences between the fasting metabolism of individuals were noted. These differences persisted on repetition of the experiments over several years. The between-sheep variation obtained in a series of determinations was $\pm 10 \%$.

5. The fasting metabolism of wether sheep aged more than 2 years and ranging in weight from 27 to $72 \mathrm{~kg}$ was about $20 \%$ lower than the recognized inter-species mean of $70.5 \mathrm{kcal} / \mathrm{kg}$ weight raised to the power 0.73 .

6. The metabolism of the wether sheep declined during the interval between about I year of age and 6 years of age by about $20 \%$.

7. During fasting, $76 \%$ of the energy lost to the body came from oxidation of fat and $24 \%$ from oxidation of protein.

8. No breed differences in metabolism were found, and comparison of the mean results with those obtained in Australia with Merino sheep and in America with Durham sheep did not reveal any racial differences in metabolism. 


\section{REFERENCES}

Armstrong, D. G. (1960). Proc. int. Grassl. Congr. viri. Reading, p. 485 .

Armstrong, D. G. \& Blaxter, K. L. (r957a). Brit. F. Nutr. rr, 247.

Armstrong, D. G. \& Blaxter, K. L. (1957b). Brit. F. Nutr. I1, 413.

Armstrong, D. G., Blaxter, K. L. \& Graham, N. McC. (1957). Brit. F. Nutr. Ir, 392.

Armstrong, D. G., Blaxter, K. L. \& Graham, N. McC. (196r). Brit. F. Nutr. r5, 169.

Benedict, F. G. (1938). Publ. Carneg. Instn, no. 503 .

Blaxter, K. L. (1950). Agric. Progr. 25, I.

Blaxter, K. L. \& Graham, N. McC. (1955). F. agric. Sci. 46, 292.

Blaxter, K. L. \& Graham, N. McC. (1956). F. agric. Sci. 47, 207.

Blaxter, K. L., Graham, N. McC. \& Rook, J. A. F. (1954). F. agric. Sci. 45, 10.

Blaxter, K. L., Graham, N. McC. \& Wainman, F. W. (1956). Proc. Nutr. Soc. 15, ii.

Blaxter, K. L., Graham, N. McC. \& Wainman, F. W. (1959). F. agric. Sci. 52, 41.

Blaxter, K. L. \& Martin, A. J. (1962). E.A.A.P. Publ. (In the Press.)

Blaxter, K. L. \& Wainman, F. W. (196r). F. agric. Sci. 57, 4r 9.

Brody, S. (1945). Bioenergetics and Growth. New York: Reinhold Publishing Corp.

Brody, S. \& Proctor, R. C. (1932). Res. Bull. Mo. agric. Exp. Sta. no. I66.

Forbes, E. B., Fries, J. A., Braman, W. W. \& Kriss, M. (1926). F. agric. Res. 33, 59 I.

Franke, E. R. \& Weniger, J. H. (1958). Arch. Tierernähr. 9, 81.

Graham, N. McC. (1958). Energy metabolism studies with sheep. Ph.D. Thesis, University of Glasgow.

Graham, N. McC., Wainman, F. W., Blaxter, K. L. \& Armstrong, D. G. (1959). F. agric. Sci. 52, I3.

Kleiber, M. (r932). Hilgardia, 6, 315 .

Kleiber, M. (1947). Physiol. Rev. 27, 5 I I.

Kleiber, M., Regan, W. M. \& Mead, S. W. (1945). Hilgardia, 16, 5 1 г.

Lines, E. W. L. \& Pierce, A. W. (1931). Bull. Coun. sci. industr. Res. Aust. no. 55.

Lusk, G. (I93I). The Elements of the Science of Nutrition, $4^{\text {th }}$ ed. Philadelphia: W. B. Saunders Co.

Marston, H. R. (1948). Aust. F. sci. Res. B, 1, 93.

National Research Council (1935). Report of the Conference on Energy Metabolism, Pennsylvania State College. Washington: National Research Council.

Quenouille, M. H., Boyne, A. W., Fisher, W. B. \& Leitch, I. (195I). Tech. Commun. Bur. Anim. Nutr., Aberd., no. 17.

Ritzman, E. G. \& Benedict, F. G. (1930). Tech. Bull. N.H. agric. Exp. Sta. no. 43.

Ritzman, E. G. \& Benedict, F. G. (I93 I). Tech. Bull. N.H. agric. Exp. Sta. no. 45 .

Ritzman, E. G. \& Benedict, F. G. (1938). Publ. Carneg. Instn, no. 494.

Wainman, F. W. \& Blaxter, K. L. (1958). E.A.A.P. Publ. no. 8, p. 85. 